\title{
Linkage studies on a new dominant mutant, extra-jointed palp, and three other mutants in the mosquito Aedes togoi
}

\author{
Takeo TADANO* \\ * Department of Medical Zoology, St. Marianna University School \\ of Medicine, Kawasaki, Kanagawa 213, Japan
}

(Received: July 4, 1980)

\begin{abstract}
Two mutants, hairless-antenna $(h a)$ and white-eye (w), in Aedes togoi had been previously reported to be located on the same side of the pigmented pupa (p) locus in linkage group 2, but the gene sequence of these three alleles had not been determined by the three-point experiments. This study confirmed that the gene sequence is $p$-ha-w, and showed that the recombination units between $p$ and $h a$ range from 11.9 to 38.4 and the units between $h a$ and $w$ are more than 32.4.

A new mutant, extra-jointed palp $(E x)$ is the first dominant mutant described in Aedes togoi. The Ex allele exhibited very low penetrance of $34 \%$ and was found to be located over 32.5 map units far from the $r u$ (ruby-eye) locus in linkage group 2. The $E x$ trait is sex-limited, expressed in only female palps; in the $E x$ female there is an additional segment extended from a normal palp. This extra segment is pointed and covered with white scales instead of black ones.
\end{abstract}

The white-eye allele $(w)$ has been placed on the same side as the hairless-antenna allele $(h a)$ in respect to the pigmented pupa ( $p$ ) locus of linkage group 2 in Aedes togoi (Tadano, 1979, 1980); the ha allele was located as far as 18 to 23 map units from the $p$ locus and there existed a still farther recombination distance of 31 to 47 map units between $p$ and $w$. It, thus, appears that the gene sepuence is $p-h a-w$, but this sequence had not been confirmed by threepoint backcrosses in the previous study (Tadano, 1980). This confirmation has been made by this study.

Meanwhile, a dominant mutant, extrajointed palp $(E x)$, was found in an inbreeding subcolony of the Miura strain in April, 1977 and this is the first dominant mutant to be described in this species.

* 只野長夫 : 聖マリアンナ医科大学病害動物学教室 （元213 川崎市高津区菅生 2095）

\section{MATERIALS AND METHODS}

The methods for rearing and crossing the mosquitoes were nearly the same as previously reported (Tadano, 1977), but the mosquito larvae obtained by experimental crosses were reared in salted tap water ( $c a .2 \%$ $\mathrm{NaCl}$ ), which gave higher survival rates of the larvae. Four wild-type strains from Taipei (Taiwan), Nagasaki, Manazuru and Miura cities (the last two cities are in Kanagawa Prefecture), were utilized throughout this study to make heterozygotes for the alleles studied.

In heterozygous genotypes given in Tables of RESULTS AND DiSCUSSION, the alleles above lines were derived from female parents and the alleles below the lines were from male parents. Since the penetrance of $h a$ and $E x$ is incomplete as will be seen later, the existence of linkage of these partially manifesting alleles was examined by the $\chi^{2}$ formula mentioned by Bailey (1961) especially for this purpose; the recombination units were calcu- 
lated by the method of maximum-likelihood.

\section{RESULTS AND DISCUSSION}

1. Determination of gene sequence of whiteeye (w), hairless-antenna (ha) and pigmented pupa $(p)$

The $w$ (Fig. 1) and $p$ alleles are completely penetrant as shown in the previous results (Tadano, 1977, 1980), but the ha trait is partially manifested as in Fig. 2, where one antenna is of wild type in the ha homozygote.

Four backcrosses containing $p$, ha and w were performed, and their results are given in Table 1. Since all three alleles are markers of linkage group 2 exhibiting no sex linkage, the cross data were not assorted according to sexes in this table. In each of the four crosses, the segregation ratio of each of $w$ and $p$ was tested for $1: 1$ by $\chi^{2}$ from the data pooled from the families (Table 2). Only in cross B the segregation ratio of $w$ showed a significant departure from the $1: 1$ ratio; here less $w$ individuals were produced than its wild-type ones. But the $p$ allele segregated at the $1: 1$ ratio in all crosses, which is indicated by insignificant $\chi^{2}$ values $(P>0.05)$. On the other hand the ha allele did not show the $1: 1$ ratio of segregation in any of four backcrosses, since much less $h a$ individuals were produced. Observed numbers of the ha and its wild-

Table 1 Results of crosses among white-eye (w), hairless-antenna $(h a)$ and pigmented pupa $(p)$

\begin{tabular}{|c|c|c|c|c|c|c|c|c|c|c|c|}
\hline \multirow{4}{*}{ Cross } & \multicolumn{2}{|c|}{ Parental genotype } & \multicolumn{8}{|c|}{ Offspring phenotype } & \multirow[b]{4}{*}{$F^{*}$} \\
\hline & \multirow{3}{*}{\multicolumn{2}{|c|}{ Female $\times$ Male }} & + & + & + & + & $p$ & $p$ & $p$ & $p$ & \\
\hline & & & + & + & $w$ & $w$ & + & + & $w$ & $w$ & \\
\hline & & & + & $h a$ & + & ha & + & ha & + & $h a$ & \\
\hline A. & $\frac{t+t}{w h a p}$ & $\frac{w h a p}{w h a p}$ & 62 & 8 & 43 & 3 & 52 & 14 & 44 & 22 & 3 \\
\hline B. & $\frac{w h a p}{t+t}$ & $\frac{w h a p}{w h a p}$ & 63 & 3 & 40 & 3 & 55 & 10 & 47 & 9 & 3 \\
\hline C. & $\frac{w h a p}{w h a p}$ & $\frac{t+t}{w h a p}$ & 186 & 4 & 134 & 10 & 146 & 28 & 131 & 54 & 10 \\
\hline D. & $\frac{w h a p}{w h a p}$ & $\frac{w h a p}{t+t}$ & 255 & 4 & 199 & 5 & 162 & 26 & 190 & 33 & 11 \\
\hline
\end{tabular}

* Families pooled.

Table $2 \chi^{2}$ analysis of crosses $\mathrm{A}$ through $\mathrm{D}$ and recombination units between $w$, ha and $p$

\begin{tabular}{ccccc}
\hline \hline & \multicolumn{3}{c}{ Cross } \\
\cline { 2 - 5 } & $\mathrm{A}$ & $\mathrm{B}$ & $\mathrm{C}$ & $\mathrm{D}$ \\
\hline $1: 1$ segregation $\left(\chi^{2}\right.$ values & & & & \\
$+: w$ & 2.32 & $4.46^{*}$ & 0.30 & 0.46 \\
$+: p$ & 1.04 & 0.62 & 0.04 & 3.10 \\
$\chi^{2}$ values for linkage between & & & & \\
$p-h a$ & $7.83^{* *}$ & 6.12 & $54.46^{* *}$ & $46.56^{* *}$ \\
$h a-w$ & 1.50 & 0.28 & $13.93^{* *}$ & $9.27^{* *}$ \\
$p-w$ & 2.29 & 0.85 & 1.92 & 1.46 \\
$p-h a$ & & & & \\
$h a-w$ & 38.4 & 26.0 & 14.8 & 11.9 \\
$p-w$ & free & free & 32.4 & 44.8 \\
Recombination units between & free & free & free & free \\
\hline
\end{tabular}

* Significant at the $5 \%$ level.

** Significant at the $1 \%$ level. 




1



2

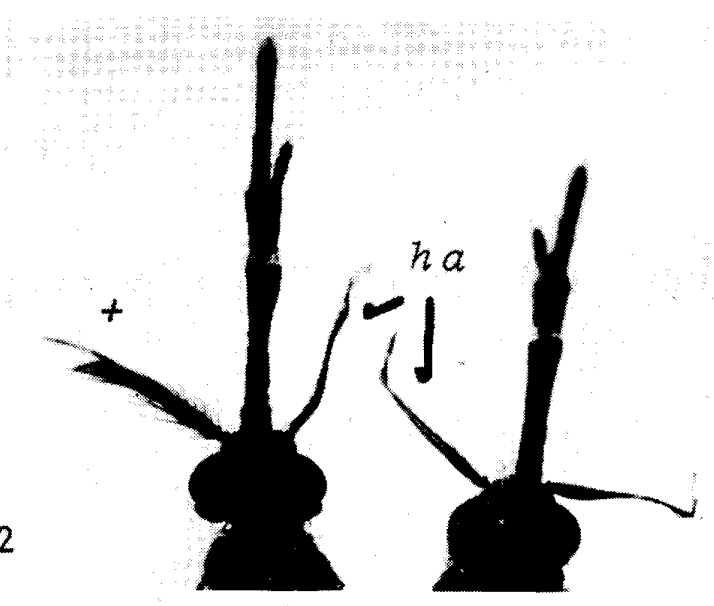

4

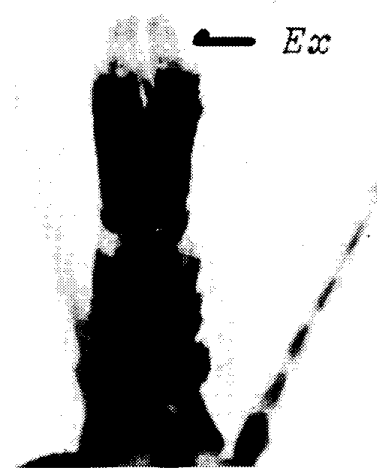

Fig. 1 Wild-type $(+)$ and white $(w)$ eyes

Fig. 2 Hairless-antenna $(h a)$, and wild-type antenna $(+)$ in the male with partial manifestation of $h a$

Figs. 3 and 4 Wild-type palp (+) and extra-jointed palp $(E x)$

type $\left(h a^{+}\right)$individuals were : $47 \mathrm{ha} / 201 \mathrm{ha}^{+}$ (cross A), $25 h a / 205 h a^{+}$(B), $96 h a / 617 h a^{+}$ (C) and $68 \mathrm{ha} / 806 \mathrm{ha}^{+}$(D). Total numbers of the $h a$ and wild-type individuals, accumulated from the four crosses, were 236 and 1,829 , respectively. Therefore, the penetrance of $h a$ is roughly $236 / 1,829=13 \%$.

The presence of linkage between $w$, ha and $p$ was examined by $\chi^{2}$-tests (Table 2 ). Strong linkage between $p$ and $h a$ is clearly indicated by the $\chi^{2}$ values in all four crosses, and also the $\chi^{2}$ values in crosses $C$ and $D$ suggest the existence of linkage between $h a$ and $w$. However, all $\chi^{2}$ values testing for linkage between $p$ and $w$ are not significant $(P>0.10$, d. f. $=1)$. Therefore, these $\chi^{2}$ values indicate that the gene sequence is $p$-ha-w and free recombination can occur between $p$ and $w$. Also the recombination units calculated (Table 2) from data of crosses $C$ and $D$ gave another evidence for the gene sequence of $p$-ha-w. The map units for $p$-ha were very various, ranging from 11.9 (D) to 38.4 (A) and those for $h a-w$ were over 32.4. 2. Linkage studies on a new dominant mutant, extra-jointed palp (Ex)

In the $E x$ female palp there is an additional pointed segment extending beyond the apical segment (Figs. 3 and 4); this extra segment is covered with white scales and therefore appears like a white point. The $E x$ phenotype is not expressed in the male palp and so shows sex-limited inheritance.

The phenotypes very similar to the $E x$ trait have been described in Aedes aegypti by Craig and Hickey (1967) who called it 5-jointed (5-j), and also in Culex tritaeniorhynchus by Baker and Sakai (1974) who gave the mutant nomenclature of extra jointed palpi $(e x)$. Both 5-j and $e x$ are recessive. The penetrance of the 5-j allele in Ae. aegypti was very poor and then was discarded; whereas $e x$ is a completely penetrant allele located in linkage group 1 of $C$. tritaenio- 
Table 3 Results of crosses between ruby-eye $(r u)$ and extra-jointed palp (Ex)

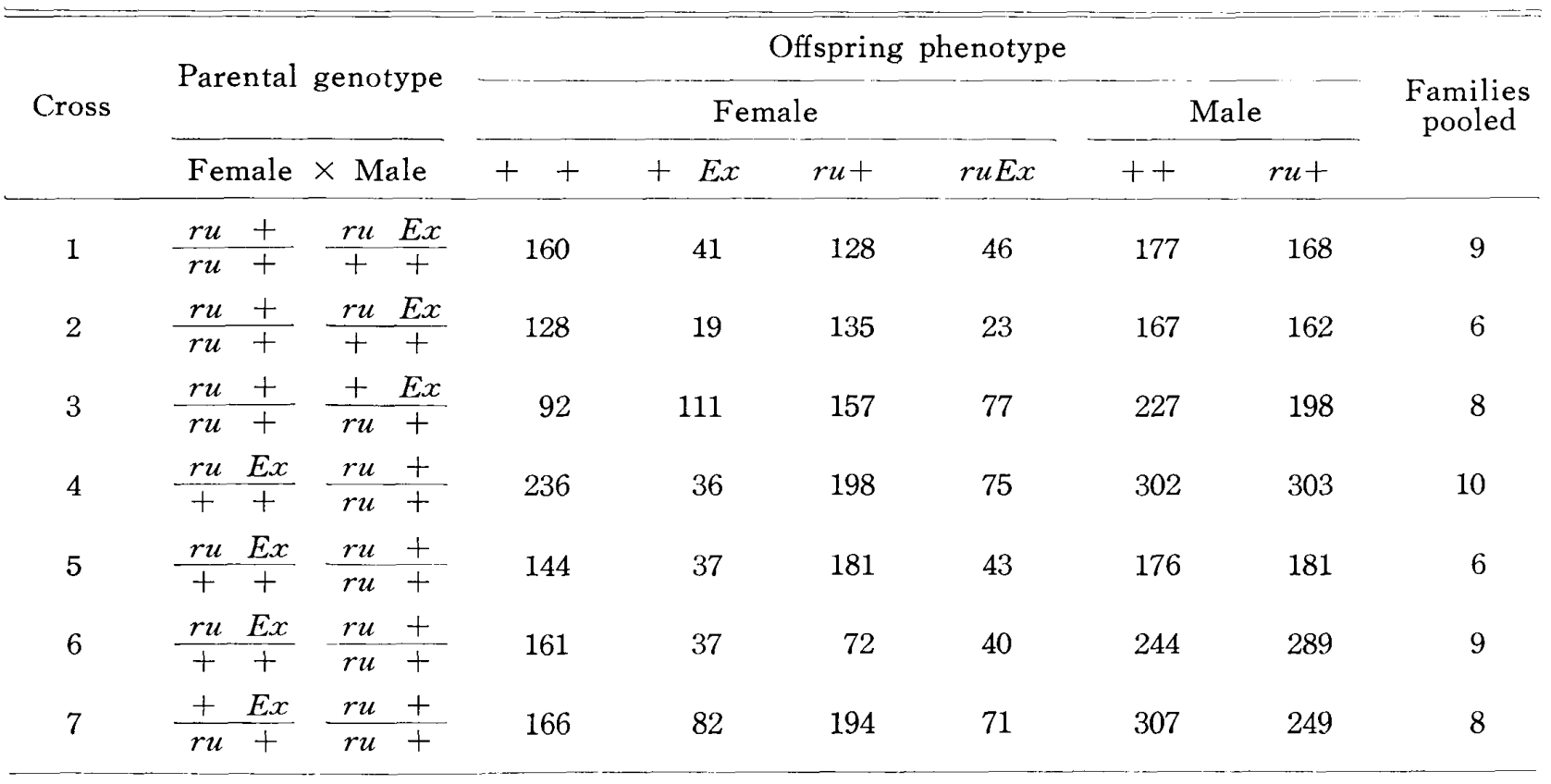

Table $4 \chi^{2}$ analysis of cross data and recombination units between $r u$ and $E x$

\begin{tabular}{lccccccc}
\hline & Cross & 1 & 2 & 3 & 4 & 5 & 6 \\
\hline $\begin{array}{l}\chi^{2} \text { values for } \\
r u:+ \text { segregation }(1: 1)\end{array}$ & 0.36 & 0.03 & 0.00 & 0.00 & 3.02 & 0.96 & 1.58 \\
$\begin{array}{l}\chi^{2} \text { values for } \\
\text { linkage between ru and } E x\end{array}$ & 1.90 & 0.17 & $20.92^{* *}$ & 17.03 & 0.10 & $10.24^{* *}$ & 2.41 \\
Recombination units & free & free & 37.6 & 32.5 & free & 34.4 & free \\
\hline
\end{tabular}

** Significant at the $1 \%$ level.

rhynchus.

Since a preliminary cross done prior to this study had provided evidence for linkage between $E x$ and $r u$ (ruby-eye) in linkage group 2, seven crosses involving only $E x$ and $r u$ were made as given in Table 3 . Crosses 1 and 2 are of the same type, but the heterozygous male parents in the two crosses were produced by hybridization with two different wild-type strains; similarly, crosses 4,5 , and 6 are replicates, employing the heterozygous female parents that were made by hybridization with three wild-type strains.

No Ex male progeny appeared in any of the seven crosses, which indicated sex-limited inheritance of Ex. Although the $E x$ allele is obviously dominant, the segregation ratios of this allele departed far from the $1: 1$ ratio in each cross and actual numbers of the individuals obtained were as follows :

$87 E x / 288$ wild type $\left(E x^{+}\right)$from cross 1

$42 \quad \prime \prime / 263$
$188 E x / 249$ wild type $\left(E x^{+}\right)$from cross 3

$\begin{array}{rlll}111 & \prime \prime / 438 & \prime \prime & 4 \\ 80 & \prime \prime / 325 & \prime \prime & 5 \\ 77 & \prime \prime 233 & \prime \prime & 6 \\ 153 & \prime \prime / 360 & \prime \prime & 7\end{array}$

Then, total numbers of the $E x$ and its wildtype individuals scored from all crosses are 738 and 2,156 , respectively. Thus, the penetrance of $E x$ was $738 / 2,156=34 \%$.

Meanwhile, the $r u$ allele segregated at the 1:1 ratio in each of all crosses. This is certified by the $\chi^{2}$ values for segregation of $r u:+(1: 1)$, all values being insignificant at the $5 \%$ level (Table 4 ). It was again examined by $\chi^{2}$ whether $E x$ was linked to $r u$ or not; three $\chi^{2}$ values for linkage, calculated from crosses 3,4 and 6 , were significant at the $1 \%$ level, confirming the presence of linkage between $r u$ and $E x$, although the $\chi^{2}$ values from crosses $1,2,5$ and 7 were not significant because of a far distance between the $r u$ and $E x$ loci, and 
probably because of poor penetrance of $E x$. The recombination units between $r u$ and $E x$, which were estimated from the results of crosses 3,4 and 6 , were as many as 32.5 to 37.6 (Table 4). But further cross experiments to determine the $E x$ locus more precisely could not be undertaken since there was no more suitable marker available for this intention.

\section{ACKNOWLEDGEMENTS}

The author wishes to thank Mrs. S. Sugiyama of our laboratory for rearing mosquitoes. This study was supported by a grant from the Ministry of Education Science and Culture of Japan.

\section{REFERENCES}

Bailey, N. T. J. (1961) : Introduction to the mathematical theory of genetic linkage. 298 pp., Oxford University Press, Oxford.

Baker, R. H. and R. K. Sakai (1974): Genetic studies on Culex tritaeniorhynchus. In The Use of Genetics in Insect Control. R. Pal and M. J. Whitten (ed.), pp. 133-182. Elsevier/ North-Holland.

Craig, G. B., Jr. and W. A. Hickey (1967): Genetics of Aedes segypti. In Genetics of Insect Vectors of Disease. J. W. Wright and R. Pal (ed.), pp. 67-131. Elsevier/North-Holland.

Tadano, T. (1977): Genetics of three new mutants, straw-colored larva, ruby eye and pigmented pupa, in Aedes (Finlaya) togoi (Diptera: Culicidae). J. Med. Entomol., 14:3337 .
Tadano, T. (1979): Two new mutants, hairless antenna and notch wing, in Aedes togoi. Mosq. News., 39 : 506-513.

Tadano, T. (1980): Genetics of white eye in a mosquito Aedes togoi. Ann. Trop. Med. Parasitol., in press.

\section{摘 要}

トウゴウヤブカにおける white-eye, hairlessantenna, pigmented pupa の遺伝子配列 と優性突然変異体 extra-jointed palp について

トウゴウヤブカ Aedes togoi の突然変異体のうち, hairless-antenna $(h a)$ と white-eye $(w)$ とは第 2 連鎖 群の pigmented pupa $(p)$ 遺伝子座位から同じ方向に 連鎖していることをすでに報告した。それによると， ha は $p$ から 18 23 map unit の距離汇存在し, ま た, wは $p$ から 31 47 map unit の位置に存在する. この組換距離からみれば, 遺伝子配列は $p$ - ha-w の順で あるように考えられる. しかし, 前報では 3 点実験でそ の配列は確かめられていない。

そこで, 今回, $p, h a, w$ を用いた 3 点実験で遗伝子配 列が $p$ - $h a-w$ であることを確認した。 $p$ と $h a$ との組 換距離は 11.9 38.4 map unit であった.このように交 配実験によって組換価に差ができたのは，ha の浸透度 が非常に低いことに起因する。

この蚊では, extra-jointed palp $(E x)$ ははじめて記載 される優性突然変異である。これは雌の触しゅ（palp） にだけ現れる表現型であり，一種の限性遺伝である。野 生型の palpにさらにもう1節 (segment) が追加された もので，この余分な 1 節は白鱗でおおわれている. $E x$ も浸透度が悪いが，第 2 連鎖群の $r u$ (ruby-eye) から 32.5 map unit 以上離れたところに位置していることが わかった。 